Biochemistry Laboratory, St. James' Hospital, London, who carried out all the biochemical investigations.

\section{REFERENCES}

Abramson, H. A. (1926). Arch. intern. Med., 37, 291.

Aird, I. (1953). In The Management of Abdominal Operations, edited by $R$. Maingot. Lewis, London.

Barry, K. G., and Malloy, J. P. (1962). F. Amer. med. Ass., 179, 510.

Braun, W. E., and Lilienfield, L. S. (1962). F. clin. Invest., 41, 1347.

Brod, J. (1953). Acta med. Acad. Sci. hung., 4, 369.

- and Sirota, J. H. (1948). F. clin. Invest., 27, 645.

Cattell, W. R., and Birnstingl, M. (1964). Brit. F. Surg., 51, 72.

Clairmont, P., and Von Haberer, H. (1911). Mitt. Grenzgeb. Med. Chir. 22, 159 .

Dawson, J. L. (1964a). Brit. med. 7., 1, 810.

Dawson, J. L. (1964a). Brit. med. f.,

二 and Stirling, G. (1964). Arch. Path., 78, 254.
De Wardener, H. E. (1955). Anaesthesia, 10, 18

Doolan, P. D., Alpen, E. L., and Theil, G. B. (1962). Amer. F. Med., 32,65 .

Eliahou, H. E. (1964). Brit. med. F., 1, 807.

Finckh, E. S. (1962). Lancet, 2, 330.

Habif, D. V., Papper, E. M., Fitzpatrick, H. F., Lowrance, P., Smythe, C. McC., and Bradley, S. E. (1951). Surgery, 30, 241.

Lauson, H. D., Bradley, S. E., and Cournand, A. (1944). F. clin. Invest.,

23, 381.
Robinson, J. R. (1954). Reflections on Renal Function. Blackwell, Oxford.

Selkurt, E. E., Hall, P. W., and Spencer, M. P. (1949). Fed. Proc., 8, 143.

Sevitt. S. (1959). Lancet, 2, 135

Shannon, J. A. (1935) f. clin. Invest., 14, 403.

Smith, H. W. (1943). Lectures on the Kidney. Lawrence, Kansas, Univ. of Kansas Division.

Steinitz, K., and Türkand, H. (1940). 7. clin. Invest., 19, 285.

Williams, R. D., Elliott, D. W., and Zollinger, R. M. (1960). Arch. Surg., 81, 334.

Zollinger, R. M., and Williams, R. D. (1956). Surgery, 39, 1016.

\title{
Hospital Infection with Pseudomonas pyocyanea: An Investigation by a Combined Pyocine and Serological Typing Method*
}

\author{
A. H. WAHBA, $†$ PH.D., M.B., B.CH., D.T.M.\&H., DIP.BACT.
}

Brit. med. F., 1965, 1, 86-89

It is probable that Ps. pyocyanea has always been an important human pathogen, but many workers believe that it now causes more infections in hospitals than formerly (Forkner et al., 1958 ; Finland et al., 1959 ; Barber, 1961). A pyocine typing method was recently introduced (Wahba, 1963 ; Darrell and Wahba, 1964) to study the epidemiology of Ps. pyocyanea in hospitals. It is fairly simple to perform, but has the disadvantage that only 11 types can be distinguished. Habs (1957) showed that the serological typing of Ps. pyocyanea was practicable if suitable methods were used for the preparation of the sera. In an attempt to increase the number of recognizable subdivisions of the organisms a slide-agglutination technique of serological typing was investigated in parallel with pyocine typing.

\section{Materials and Methods}

Strains.-The two typing methods were used on 1,899 cultures of Ps. pyocyanea from a variety of sources. They included collections isolated from patients in a large number of different hospitals in the United Kingdom and in 12 other countries, as well as strains isolated from the hospital environ-

* This paper formed part of a thesis approved by the University of London for the degree of Ph.D.

+Cross-Infection Reference Laboratory, Central Public Health Laboratory, London. Present address: Depar ment of Baceriolozy, Lontory, London. Present address : ment, animals, plants, water, and milk (Wahba, 1964). Among them were 305 strains isolated in the course of investigations 'in 12 wards in 10 hospitals, which are considered in greater detail.

\section{Pyocine Typing}

The strains were examined for their ability to produce bacteriocines $^{1}$ (pyocines) active against 12 indicator strains by the cross-streaking method (Wahba and Lidwell, 1963 ; Darrell and Wahba, 1964). The patterns produced by the different types were labelled by capital letters A-P and the non-typable strains by N.T. (Table I).

\section{Serological Typing}

Eighteen cultures were used for the preparation of antisera ; these comprised the 12 type strains of Habs (1957), four strains described by Véron (1961) as being subtypes of Habs's types 2 and 5, the representative strain of type 13 (Sandvik, 1960 ; Véron, 1961), and type 14 (Wahba, 1964) (see Table II). As

1 Bacteriocines are antibiotic substances known at present to be produced by 19 different bacterial genera, their characteristic feature keing that their spectrum of activity is mainly limited to other members of particular species. This property has been used for typing several groups of organisms.

\begin{tabular}{|c|c|c|c|c|c|c|c|c|c|c|c|c|}
\hline \multirow{2}{*}{ Type } & \multicolumn{12}{|c|}{ Indicator Strain } \\
\hline & M 8 & B 10 & S 17 & B 26 & B 39 & A 52 & $8 / 39$ & $10 / 55$ & H 1180 & M 283 & H 323 & E 826 \\
\hline $\begin{array}{l}\text { A } \\
\text { B } \\
\text { C } \\
\text { D } \\
\text { F } \\
\text { G } \\
\text { K } \\
\text { L } \\
\text { O } \\
\text { P } \\
\text { N.T. }\end{array}$ & $\begin{array}{l}+ \\
+ \\
+ \\
+ \\
+ \\
\pm \\
= \\
+ \\
\pm\end{array}$ & $\begin{array}{l}+ \\
\pm \\
\pm \\
+ \\
+ \\
+ \\
\pm \\
= \\
=\end{array}$ & $\begin{array}{l}+ \\
+ \\
+ \\
+ \\
+ \\
+ \\
= \\
= \\
=\end{array}$ & $\begin{array}{l} \pm \\
\pm \\
\pm \\
= \\
= \\
= \\
=\end{array}$ & $\begin{array}{l}+ \\
+ \\
+ \\
+ \\
+ \\
+ \\
+ \\
\pm \\
-\end{array}$ & $\begin{array}{l}+ \\
+ \\
+ \\
+ \\
+ \\
+ \\
\pm \\
\pm \\
-\end{array}$ & $\begin{array}{l}+ \\
+ \\
+ \\
+ \\
+ \\
+ \\
+ \\
\pm \\
+\end{array}$ & $\begin{array}{l} \pm \\
\pm \\
\pm \\
= \\
= \\
= \\
= \\
=\end{array}$ & $\begin{array}{l}\bar{z} \\
\bar{z} \\
\bar{z} \\
\bar{z} \\
\bar{z}\end{array}$ & $\begin{array}{c}+ \text { or }- \\
+ \text { or } \\
\overline{-} \\
= \\
= \\
= \\
= \\
= \\
=\end{array}$ & $\begin{array}{l}+ \\
\pm \\
- \\
\pm \\
\pm \\
\pm \\
= \\
=\end{array}$ & $\begin{array}{l} \pm \\
\pm \\
+ \\
+ \\
\pm \\
\pm \\
\pm \\
=\end{array}$ \\
\hline
\end{tabular}


the subtypes within types 2 and 5 could not be confirmed in this investigation, 13 sera were in fact sufficient to type all the organisms describ. I here. As previous work had indicated that several $\mathrm{H}$ antigens could be demonstrated in one $\mathrm{O}$ group and that the same $\mathrm{H}$ antigen could be present in different $\mathrm{O}$ groups, the preparation and use of $\mathrm{H}$ antisera for the present purpose was considered unhelpful.

TABLE II.-Strains Used for Preparation of Antisera

\begin{tabular}{|c|c|c|c|c|}
\hline \multicolumn{3}{|c|}{ Origin of Strain } & $\begin{array}{l}\text { Antigenic Type } \\
\text { (Véron) }\end{array}$ & $\begin{array}{c}\text { Antigenic Type } \\
\text { (In Present Investigation) }\end{array}$ \\
\hline $\begin{array}{l}\text { Habs } 0: 1 \\
\text { Habs } 0: 2 \\
\text { Véron } 60 \mathrm{BT} \\
\text { Véron } 61 \mathrm{~B} \\
\text { Habs } 0: 3 \\
\text { Habs } 0: 4 \\
\text { Habs } 0: 5 \\
\text { Véron } 60 \mathrm{BL} \\
\text { Véron } 59 \mathrm{AH} \\
\text { Habs } 0: 6 \\
\text { Habs } 0: 7 \\
\text { Habs } 0: 8 \\
\text { Habs } 0: 9 \\
\text { Habs } 0: 10 \\
\text { Habs } 0: 11 \\
\text { Habs } 0: 12 \\
\text { Sandvik } 11 \\
\text { Wahba } 889\end{array}$ & 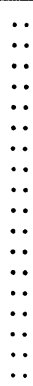 & $\begin{array}{l}\because \\
\because \\
\because \\
\because \\
\because \\
\because \\
\because \\
\because \\
\because \\
\therefore\end{array}$ & $\begin{array}{ll}0 & 1 \\
0 & 2 \mathrm{a} \\
0 & 2 \mathrm{~b} \\
0 & 2 \mathrm{ab} \\
0 & : 3 \\
0 & 4 \\
0 & 4 \mathrm{c} \\
0 & 5 \mathrm{~d} \\
0 & 5 \mathrm{~cd} \\
0 & \vdots 6 \\
0 & \vdots 7 \\
0 & 8 \\
0 & 89 \\
0 & 10 \\
0 & 111 \\
0 & : 12 \\
0 & : 13 \\
- & \end{array}$ & $\begin{array}{r}\frac{1}{7} \\
2 \\
3 \\
4 \\
5 \\
6 \\
7 \\
8 \\
9 \\
10 \\
11 \\
13 \\
14\end{array}$ \\
\hline
\end{tabular}

A modification of the immunization technique employed by Habs (1957) was used, as this gave higher antiserum titres and eliminated fatal reactions in the rabbits. Four overnight nutrient-agar slope cultures of each strain were emulsifed in a total of $10 \mathrm{ml}$. of saline and heated for two and a half hours at $100^{\circ} \mathrm{C}$. These stock suspensions were kept at $4^{\circ} \mathrm{C}$. without the addition of preservatives. The immunization of rabbits weighing 2.5 to $3 \mathrm{~kg}$. was begun with a subcutaneous dose of $0.1 \mathrm{ml}$. After two days the following quantities were given every other day intravenously in the ear vein: $0.2,0.4,0.8,1.6$, 2 , and $2 \mathrm{ml}$. The $0.8-\mathrm{ml}$. dose was supplemented by a further $0.2 \mathrm{ml}$. subcutaneously. Four days after the last dose a blood specimen was withdrawn and tested for agglutinins; $0.1 \mathrm{ml}$. of the homologous boiled suspension (density: Wellcome Opacity Tube No. 6) was added to $1-\mathrm{ml}$. volumes of doubling dilutions of the serum $(1: 50$ to $1: 6,400)$ and incubated in a $51^{\circ} \mathrm{C}$. water-bath. The result was read after four hours. The homologous titres were $1: 1,600$ or more in every case, and the rabbits bled out.

Table III shows the homologous titres as well as the titres of cross-reactions with the other type strains. Kleinmaier (1957), who used sera prepared by Habs's method in a slide-agglutination test, found that a $1: 25$ dilution of the unabsorbed sera resulted in the disappearance of all cross-reactions. In our experience, dilution did not give entirely satisfactory results ; therefore absorptions were carried out. Saline suspensions from nutrient-agar slopes were heated for two and a half hours at $100^{\circ} \mathrm{C}$. These were then centrifuged and the sediment was added to the serum in a $1: 1$ proportion. The mixture was left two hours at $37^{\circ} \mathrm{C}$, and then 24 hours at $4^{\circ} \mathrm{C}$. After centrifugation the serum was separated. Each serum was absorbed with all cultures with which it gave any cross-reaction according to the findings in Table III. The sera were preserved with $1: 20,000$ merthiolate.

All strains isolated were tested by slide-agglutination as described by Kleinmaier (1957). For simplicity, culture material taken from an overnight nutrient-agar (Oxoid) plate or slope was first tested with three pools containing equal volumes of undiluted sera: Pool I (types 1, 3, 4, 6, 9, and 11), Pool II (types 7, 8, 10,12, 13, and 14), and Pool III (types 2a, $2 \mathrm{~b}, 2 \mathrm{ab}, 5 \mathrm{c}, 5 \mathrm{~d}$, and $5 \mathrm{~cd}$ ). Then individual type identification with sera at a working dilution of $1: 25$ was performed. In some instances, when the strain appeared to be autoagglutinable, it was plated out on other media such as nutrient agar No. 2 (Oxoid) or MacConkey agar, and separate colonies were tested. All observations were made by the naked eye. The growth on nutrient agar was often rather viscous and difficult to emulsify in saline. We found it more satisfactory, therefore, to transfer a mass of bacterial growth to the slide near a drop of serum, and to scrub it vigorously on the glass before incorporating it in the serum. With sera of adequate potency the specific agglutination reaction appeared within a few seconds as dense aggregations of bacteria with a clear background. Loose, viscous aggregations sometimes appeared quickly but did not progress to full agglutination; they were ignored. On rare occasions (less than $3 \%$ of all cultures) strains reacted with two or more sera, but agglutination was always more rapid with one particular serum, and the strain was considered to belong to the corresponding type. Strains autoagglutinable in $3.5 \%$ saline or normal rabbit serum were very few-three in the large series of 1,899 strains. In addition there were three other strains which were not agglutinated by any of the sera. There was no cross-agglutination between Ps. pyocyanea and a group of 62 strains belonging to various Pseudomonas species when the sera were used in the working dilution. With undiluted sera a slight atypical fine agglutination was occasionally seen.

\section{Results}

Table IV shows the relation between the pyocine and the serological types in the whole series of 1,899 cultures. The 22 different sero-pyocine types resulting from the combination of the two typing systems are also shown.

Table $\mathrm{V}$ shows the number of strains in each sero-pyocine type as found in 12 different hospital wards, together with the respective periods of observation. It will be noted that in certain relatively short outbreaks one type predominated. Whenever the investigation was continued for some months, however, representatives of a number of different types were found.

TABLE III.-Cross-reactions between Ps. pyocyanea Typing Sera. Titres of Homologous and Heterologous Reactions in Tube Agglutination Tests with Unabsorbed Sera

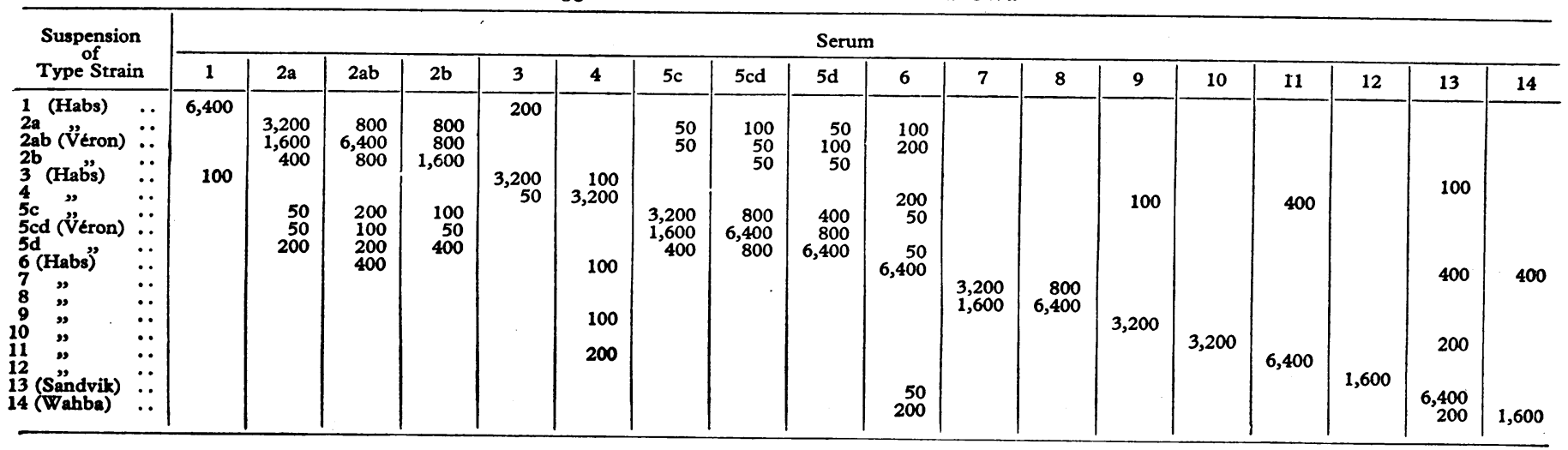




\section{Discussion}

When the pyocine typing system was widely applied (Wahba, 1964) it became apparent that four types (A, B, D, and F) accounted for over $70 \%$ of all strains examined and formed the majority of strains in any large series from one particular epidemiological focus. With serological typing the strains were rather more widely dispersed among the serotypes; nevertheless four types $(1,2,5$, and 6$)$ predominated, accounting for more than $60 \%$ of the cultures tested. When both methods were combined a useful increase in number of subdivisions resulted. None of these new subdivisions, apart from strains belonging to pyocine type $\mathrm{D}$ and serological type 6 , is so common that it introduces difficulties. Both typing techniques are fairly simple and rapid, once the sera for serological typing have been prepared.

In certain urological and paediatric wards one type of organism was often found predominant and gave rise to the majority of clinical infections. In extreme cases a single strain may be responsible for all infections over a period of several weeks or longer. Short, acute clinical epidemics due to single types were observed in a respiratory inadequacy unit and a colonic surgery ward. Several epidemics, due to single strains, were also observed in premature-baby units ; these may persist for many months unless adequate preventive measures are taken. In burns wards, where there is a high rate of bacteriological infection, one strain usually predominates for quite long periods of time. With regard to the otological and ophthalmic wards, there was considerable heterogeneity among the organisms responsible for clinical infection; this would indicate that many of the patients were admitted with strains of their own.

Our experience at Hammersmith Hospital (Darrell and Wahba, 1964) also suggested that in surgical wards with a relatively low incidence of clinical disease due to $P$ s. pyocyanea a number of different types were brought in from time to time by the patients and that a considerable proportion of the infections were autogenous.

The essential difference between the situations in the different types of hospital ward seemed to be in the proportion of the susceptible individuals present. When they were few, infection was speading slowly and the lesions were due to a variety of different $P$ s. pyocyanea types. When they were many, a particular strain often gained temporary ascendancy and was responsible for most of the infections for weeks or even months.

\section{Summary}

Ps. pyocyanea infection was investigated in several types of hospital wards by using a combined pyocine and serological typing method. In wards in which the rate of clinical infection was high-notably urinary, paediatric, respiratory inadequacy, and burns units-it was common for one particular type of organism to be responsible for most of the infections. Whenever highly susceptible patients came in contact with heavy disseminators of the organism, cross-infection was common.

I wish to thank Dr. M. T. Parker, Director, Cross-Infection Reference Laboratory, Central Public Health Laboratory, for his

TABle IV.-Correlation between Pyocine Types and Serological Types

\begin{tabular}{|c|c|c|c|c|c|c|c|c|c|c|c|c|c|c|c|c|}
\hline \multirow{2}{*}{$\begin{array}{l}\text { Pyocine } \\
\text { Types }\end{array}$} & \multicolumn{16}{|c|}{ Serotypes } \\
\hline & 1 & 2 & 3 & 4 & 5 & 6 & 7 & 8 & 9 & 10 & 12 & 12 & 13 & 14 & N.T. & Total \\
\hline $\begin{array}{l}\text { A } \\
\text { B } \\
\text { C } \\
\text { D } \\
\text { G } \\
\text { G } \\
\text { K } \\
\text { D } \\
\text { P } \\
\text { N.T. }\end{array}$ & $\begin{array}{c}6 \\
19 \\
154\end{array}$ & $\begin{array}{l}155 \\
113\end{array}$ & $\begin{array}{l}91 \\
59\end{array}$ & 71 & 179 & $\begin{array}{l}535 \\
\\
\\
92 \\
19\end{array}$ & 12 & 82 & 82 & 37 & 163 & & 12 & 8 & 2 & $\begin{array}{r}194 \\
390 \\
10 \\
547 \\
234 \\
8 \\
19 \\
91 \\
82 \\
92 \\
232\end{array}$ \\
\hline Total & 179 & 268 & 150 & 71 & 179 & 650 & 12 & 82 & 82 & 37 & 163 & & 12 & 8 & 6 & 1,899 \\
\hline
\end{tabular}

TABlE V.-Number of Ps. pyocyanea Strains and Their Sero-pyocine Type in the Different Wards Studied

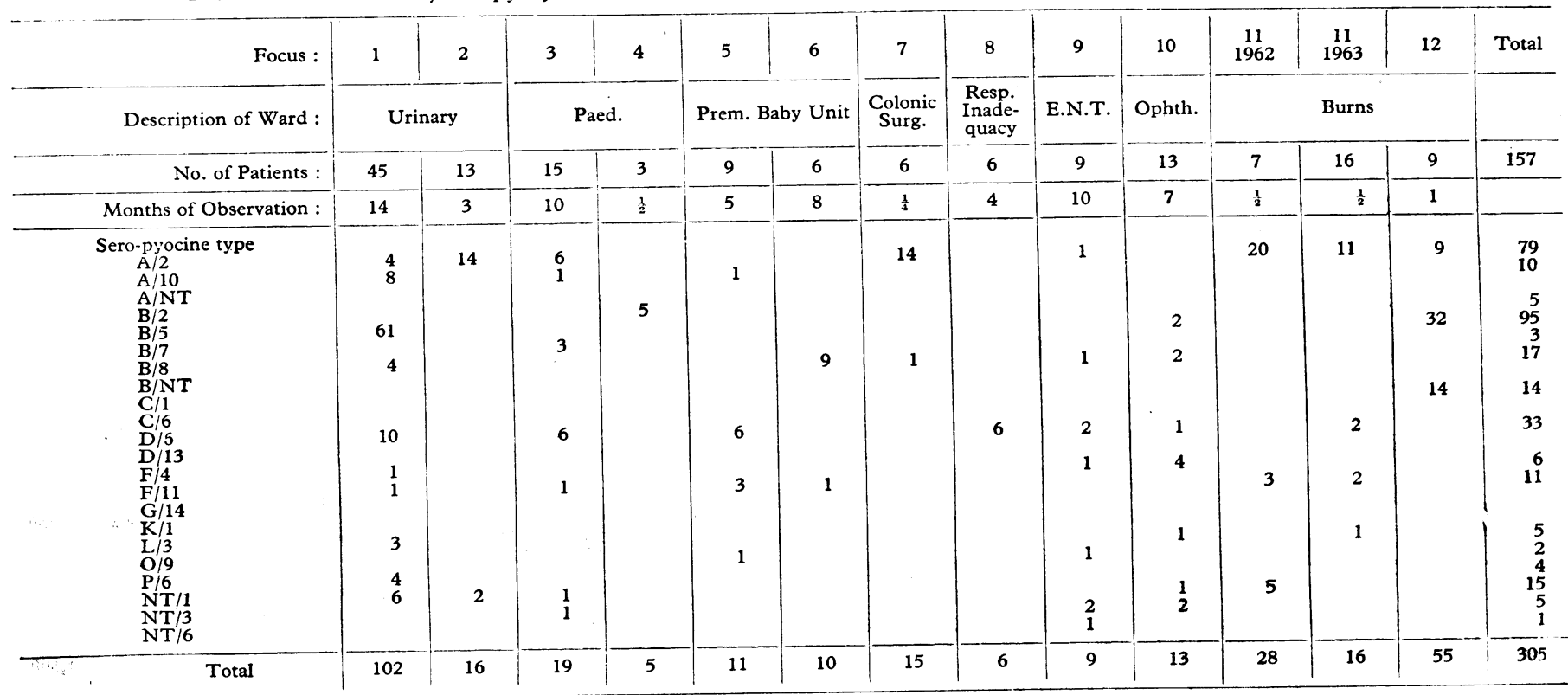


helpful advice and valuable criticism. I am also indebted to Professor Mary Barber, Postgraduate Medical School, London ; Dr. Jean Bradley, Fulham Hospital, London; Dr. J. H. Darrell, Postgraduate Medical School, London; Professor A. El Ghoroury, Institute of Hygiene, Alexandria ; Dr. E. J. L. Lowbury, M.R.C. Industrial Injuries and Burns Research Unit, Birmingham ; Dr. Joan McWilliam, Royal Infirmary, Edinburgh; Dr. L. Parker, Booth Hall Hospital, Manchester; Dr. K. B. Rogers, the Children's Hospital, Birmingham ; Dr. J. K. Schönfeld, Rotterdam ; Professor R. A. Shooter, St. Bartholomew's Hospital Medical School, London ; Dr. M. Véron, Institut Pasteur, Paris ; and Dr. Josephine A. C. Weatherall, Charing Cross Hospital, London, for sending strains and showing interest in this work.
REFERENCES

Barber, M. (1961). F. clin. Path., 14, 2

Darrell, J. H., and Wahba, A. H. (1964). Ibid., 17, 236.

Finland, M., Jones, W. F., and Barnes, M. W. (1959). F. Amer. med. Ass., 170, 2188. Forkner, C. E., Frei, E., Edgcomb, J. H., and Utz, J. P. (1958). Amer.

Habs, I. (1957). Z. Hyg. Infekt-Kr., 144, 218.

Kleinmaier, H. (1957). Zbl. Bakt., I. Abt. Orig., 170, 570.

Sandvik, O. (1960). Acta path. microbiol. scand., 48, 56.

Véron, M. (1961). Ann. Inst. Pasteur, 101, 456.

Wahba, A. H. (1963). 7. Hyg. (Lond.), 61, 431.

- (1964). Thesis, University of London.

- and Lidwell, O. M. (1963). F. appl. Bact., 26, 246.

\title{
An Investigation of Tropical Splenomegaly at Mulago Hospital, Kampala, Uganda
}

\author{
P. D. MARSDEN,* M.B., M.R.C.P. ; M. S. R. HUTT, M.D., M.R.C.P. ; N. E. WILKS, † PH.D. ; A. VOLLER,* PH.D. ; \\ V. BLACKMAN, M.B., B.S., D.C.P.; K. K. SHAH, M.B., B.S.; D. H. CONNOR, $\ddagger$ M.D. ; \\ P. J. S. HAMILTON,* M.B., CH.B. ; J. G. BANWELL, M.B., M.R.C.P. ; H. F. LUNN, F.R.C.S.
}

Brit. med. F., 1965, 1, 89-92

Idiopathic, cryptogenic, or tropical splenomegaly, as it is variously termed, is often encountered at the Mulago Hospital in Kampala. Trowell (1950) reported several cases in which no good reason could be found for gross splenomegaly, and discussed the current theories of aetiology. Leather (1961) made the important observation that many cases had a mild portal hypertension in the absence of any evidence of cirrhosis on liver biopsy. Of the 41 cases he investigated 29 showed sinusoidal infiltrates by lymphocytes, histiocytes, and plasma cells, an appearance that had been noted elsewhere in the tropics by Fawdry (1955) from Aden, and by Chaudhuri et al. (1956) from India.

The present report describes a series of cases of marked splenomegaly admitted to the New Mulago Hospital, Kampala, in which combined clinical, haematological, parasitological, and pathological investigations were carried out to assess the cause and effect of the large spleens.

\section{Materials and Methods}

Over a period of eight months 64 patients with marked splenomegaly were investigated in the New Mulago Hospital, Kampala.

Routine haematological investigations were prepared by standard techniques (Dacie, 1956). In five patients the red-cell survival and splenic uptake were estimated, using ${ }^{51} \mathrm{Cr}$-tagged red cells (Mollison and Veall, 1955), and the sites of red-cell destruction were assessed by the method of Hughes Jones and Szur (1957).

Standard liver-function tests were done in all cases and a bromsulphthalein excretion test in seven. A needle liver biopsy was performed in 58 of the 64 patients. Two patients refused biopsy and in four a definite diagnosis was possible without biopsy. Repeat biopsies were done in several cases if the first biopsy was unsatisfactory or inconclusive.

\footnotetext{
* Seconded from the London School of Hygiene and Tropical Medicine.
+ Walter Reed Army Institute of Research, Washington, D.C., U.S.A. $¥$ Armed Forces Institute of Pathology, Washington, D.C., U.S.A.
}

Splenic biopsies were carried out in 17 patients. Twenty-six cases had splenovenograms and in 37 the intrasplenic pressure was estimated by the percutaneous route (Dreyer and BudtzOlsen, 1952 ; Atkinson and Sherlock, 1954). Splenic puncture specimens were examined for malaria parasites and leishmaniae. Initially, random peripheral thick blood was examined for malaria parasites and trypanosomes, but in the latter part of the study a minimum of 10 consecutive daily blood films were examined for malaria parasites by two observers.

Stools were examined by the formol-ether-concentration technique (Ridley and Hawgood, 1956) for ova, cysts, and parasites. Rectal snips were examined for schistosome ova.

Sera from 40 patients were examined by a fluorescent antibody technique (Voller, 1964) for the presence of malarial antibodies. Control sera from patients without splenomegaly were also examined. The antigen used was Plasmodium bastianellii.

Dr. D. J. H. Payne, of the Public Health Laboratory Service in England, kindly examined 40 sera for brucella agglutinins.

\section{Results}

A final analysis of the 64 patients is shown in Table I. The diagnoses are based on both the clinical and the pathological

Table I.-Clinical Conditions and Liver Biopsy Appearances in 64 Patients with Splenomegaly

\begin{tabular}{|c|c|c|c|c|c|}
\hline \multicolumn{4}{|c|}{ Diagnosis } & $\begin{array}{l}\text { Total No. } \\
\text { of Cases }\end{array}$ & $\begin{array}{l}\text { Sinusoidal Change } \\
\text { on Liver Biopsy }\end{array}$ \\
\hline $\begin{array}{l}\text { Cirrhosis } \\
\text { Leukaemia } \\
\text { Plasmacytoma } \\
\text { Sickle-cell anaem } \\
\text { Myelosclerosis } \\
\text { Leishmaniasis } \\
\text { Schistosomiasis } \\
\text { Splenic abscess } \\
\text { Brucellosis } \\
\text { Extrahepatic obs } \\
\text { No diagnosis } \\
\text { splenomegaly }\end{array}$ & $\begin{array}{cc}\because & \quad . \\
\because & \because \\
\text { mia } & \because \\
\because & \because \\
\because & \because \\
\because & \because \\
\text { struction } \\
\text { or } & \text { obvious } \\
. & \therefore\end{array}$ & $\begin{array}{l}\because \\
\because \\
\because \\
\because \\
\because \\
\because \\
\therefore \\
\text { cause } \\
\ldots\end{array}$ & $\begin{array}{c}\because \\
\because . \\
\because \\
\because \\
\because \\
\because \\
\ddot{\text { for }} \\
\ldots\end{array}$ & $\begin{array}{r}9 \\
4 \\
1 \\
3 \\
2 \\
2 \\
2 \\
2 \\
2 \\
2 \\
35\end{array}$ & $\begin{array}{l}3 \\
2 \\
0 \\
2 \\
0 \\
0 \\
0 \\
1 \\
2 \\
1 \\
29\end{array}$ \\
\hline Total & $\ldots$ & . & . & 64 & 40 \\
\hline
\end{tabular}

